\title{
ALAT PENYIANG GULMA SISTEM LANDAK BERMOTOR
}

\author{
Dwi Rahmawati ${ }^{1}$, Suhardjono², Amal Bahariawan³ \\ 1) 2) Jurusan Produksi Pertanian, Politeknik Negeri Jember \\ 3)Jurusan Teknologi Pertanian, Politeknik Negeri Jember
}

\begin{abstract}
ABSTRAK
Penggunaan sistem tanam legowo merupakan salah satu terobosan untuk meningkatkan produksi padi. Namun penerapan sistem ini masih terkendala dengan pertumbuhan gulma yang tinggi. Pada sistem jejer legowo gulma muncul pada barisan yang lebar. Penanganan gulma selama ini dilakukan secara manual menggunakan tenaga manusia, mempunyai banyak kelemahan yaitu biaya mahal, kurang bersih dan waktu penyiangan lama. Tujuan dari kegiatan pengabdian ini adalah untuk membantu petani dalam mengatasi masalah gulma tanaman pagi yang ditanam dengan sistem tanam legowo. Target yang ingin dicapai adalah proses penyiang gulma dilakukan secara mekanis, sehingga proses penyiangan lebih cepat, biaya murah dan hasil penyiangan lebih bersih. Metode yang digunakan adalah penyiangan sistem landak bermotor. Dengan adanya tenaga motor dalam penyiangan maka hasil lebih bersih dan waktu penyiangan lebih cepat, dan tenaga lebih hemat. Dengan teknologi ini maka pertumbuhan gulma pada tanaman padi sistem legowo akan dapat teratasi, sehingga pertumbuhan tanaman padi akan lebih optimal.
\end{abstract}

Kata Kunci: Gulma, Penyiangan, Sistem Landak Bermotor

\section{PENDAHULUAN}

Penanaman padi dengan sistem jejer legowo mulai dilakukan oleh sebagian petani di Sukowono Kabupaten Jember. Hal ini terkait dengan program pemerintah daerah yang akan memasyarakatkan sistem tanam ini, karena terbukti di daerah lain memberikan hasil panen yang optimal. sistem tanam legowo mempunyai kelebihan yaitu jarak tanam lebih teratur, aliran udara lebih lancar, perkembangan anakan padi lebih terarah, dan penyiangan gulma lebih muda. Kelebihan-kelebihan tersebut sangat dirasakan oleh petani.

Namun demikian, ada kendala yang dihadapi oleh petani dalam menerapkan sistem ini yaitu sering muncul gulma terutama pada tanaman padi umur muda pada jarak tanam yang lebar, hal ini dipacu oleh kondisi air yang tidak stabil dan juga ada daerah-daerah tertentu yang pertumbuhan gulmanya cukup tinggi. Meskipun penyiangan gulma lebih muda dilakukan yaitu dengan menggunakan roda cakar yang didorong, namun kondisi ini sedikit menambah biaya dan tenaga.

Kelompok tani Taruna Tani dan Baru Muncul merupakan salah satu contoh kelompok tani yang melakukan penanam padi sistem jejer legowo. Untuk mengatasi gulma, petani ini menggunakan roda cakar yang didorong pada jalur lebar tersebut. Untuk luas lahan 1 ha tanaman padi membutuhkan pekerja sekitar 5-7 orang dengan ongkos borong mencapai Rp. 800.000,dilakukan selama 5 hari. Untuk kondisi serangan gulma yang cukup tinggi biaya penyiangan bisa mencapai 2 kali lipat, sehingga dirasakan oleh petani biaya terbesar dalam usaha tani padi adalah biaya penyiangan. Penangan tidak serius terhadap gulma akan mengakibatkan pertumbuhan tanaman padi tidak optimal dan untuk serangan yang lebih parah akan menyebabkan gagal panen. AAK (1990) menyatakan bahwa jika penyiangan gulma tidak 
dilakukan pada masa-masa pertumbuhan, maka tanaman padi akan mendapat persaingan dalam memperoleh makanan, sehingga membawa akibat produksi gabah merosot.

Dengan pertimbangan tersebut di atas maka kelompok tani mengharapkan adanya teknologi baru untuk melakukan penyiangan dengan biaya yang relatif lebih murah dan hasil yang lebih bersih. Teknologi mesin penyiang gulma tanaman padi sistem cakar putar bermotor merupakan teknologi penyiangan yang tepat untuk diterapkan di kelompok tani untuk tanaman padi sistem legowo. Hal ini sesuai dengan pernyataan AAK (1990) bahwa penyiangan menggunakan alat roda penyiang (landak) akan lebih baik apabila didukung oleh penanaman yang teratur, yakni dengan cara larikan.
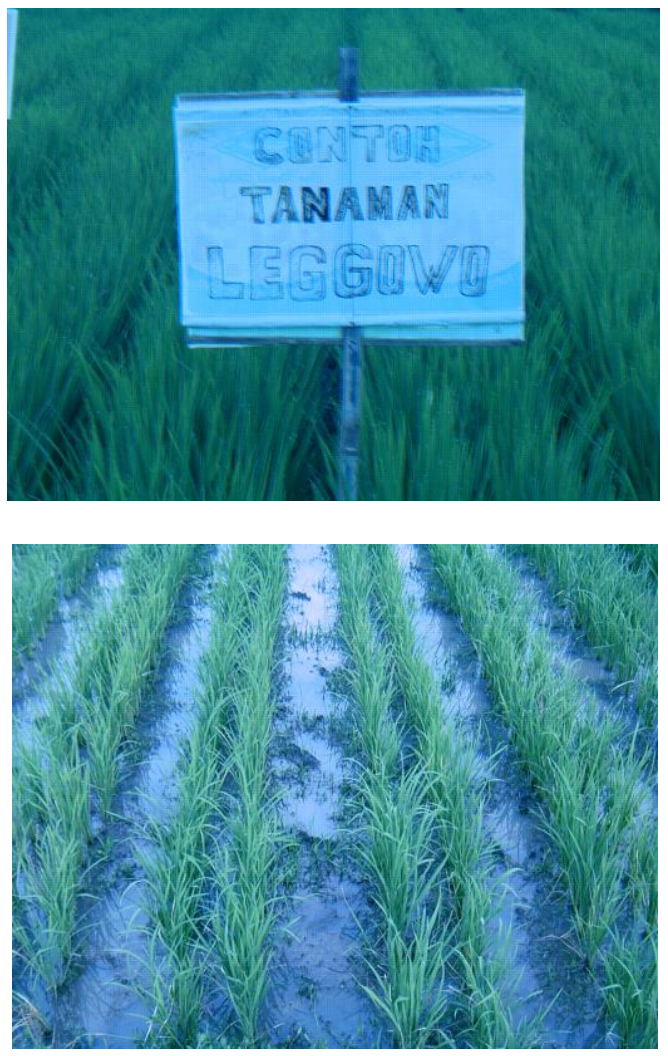

Gambar 1. Gulma Mulai Tumbuh di Jalur Lebar

\section{TARGET DAN LUARAN}

Target luaran dari kegiatan ini adalah:
a. Menyempurnakan sistem tanam leggowo terutama pada penanganan gulma.

b. Mempercepat penyiangan gulma menjadi 3 kali lebih cepat dari cara manual dengan tenaga manusia.

c. Mengurangi biaya penyiangan gulma 3 kali lebih kecil

d. Mengurangi resiko kerusakan tanaman dan hasil penyiangan gulma lebih bersih.

e. Membuat 2 unit mesin penyiang gulma sistem landak bermotor

\section{METODE PELAKSANAAN}

Untuk mengatasi permasalahan yang terjadi pada petani mitra terkait dengan pertumbuhan gulma di lahan budayanya maka dilakukan beberapa langkah yaitu:

1. Studi pustaka dan observasi lapang

Dalam merekayasa mesin penyiang gulma tanaman padi diperlukan studi pustaka mengenai:

a. Teknik budidaya tanaman padi sistem tanam leggowo meliputi: cara penanaman, pemupukan, pengairan, penyiangan dan pemanenan.

b. Sifat-sifat dan jenis gulma tanaman Padi

c. Teknik penyiangan meliputi: cara penyiangan, macam peralatan penyiangan.

d. Teknik perancangan alat dan mesin pertanian khususnya mesin penyiang gulma.

2. Studi Lapang yang dilakukan adalah:

a. Mengamati pertumbuhan gulma pada tanaman Padi mulai dari penanam sampai panen.

b. Mengamati cara penyiangan gulma yang dilakukan secara manual.

c. Mengamati peralatan yang dipergunakan untuk penyiangan. 
3. Rancang Bangun Mesin Penyiang Gulma untuk Tanaman Padi Sistem Leggowo

Mesin penyiang gulma didesain untuk tanaman Padi dengan jarak tanaman membujur antara $30 \mathrm{~cm}$. Kerja mesin penyiang ini menggunakan sistem cakar dengan pisau cakar berderet pada sebuah as. Dengan sistem ini diharapkan gulma akan tercabut sampai ke akarnya. Tenaga penggerak untuk memutar pisau menggunakan motor bensin $3 \mathrm{HP}$ sedangkan untuk berjalan menggunakan tenaga dorong manusia. Gambaran mesin penyiang gulma untuk tanaman padi secara lengkap dapat dilihat pada lampiran 2 .

Mesin penyiang gulma untuk tanaman padi yang dibuat ini terdiri dari beberapa bagian utama yaitu:

a. Unit Pencakar Gulma

Unit ini sangat menentukan keberhasilan penyiangan gulma untuk itu pembuatan unit ini sangat diperhatikan. Komponen utama terdiri dari pisau cakar dan as. Pisau cakar terbuat dari bahan baja dengan bentuk modifikasi dari pisau bajak rotary. Jumlah pisau cakar sebanyak 3 buah dengan jarak masing-masing $10 \mathrm{~cm}$. As yang digunakan besi as diameter $3 / 4$ dim yang digerakkan dengan sistem transmisi gardan lunak.

b. Unit Transmisi

Transmisi yang digunakan untuk menggerak pisau cakar menggunakan sistem gardan lunak diharapkan tidak akan ada slip tenaga. Untuk keamanan motor penggerak sudah terdapat di dalam sistem tranmisi motor itu sendiri. Gardan lunak yang digunakan ukuran kecil untuk mengurangi beban motor terlalu besar.

c. Unit Tenaga Penggerak

Tenaga penggerak menggunakan motor bensin 3 HP. Daya ini diharapkan sudah aman untuk menggerak pisau cakar untuk melakukan penyiangan pada kondisi tanah sawah.

\section{d. Unit Rangka}

Rangka dirancang seergonomis mungkin sehingga dapat memberikan kenyamanan dalam melakukan penyiang gulma. Rangka ini dibuat untuk menopang motor penggerak, pisau cakar, sistem transmisi,

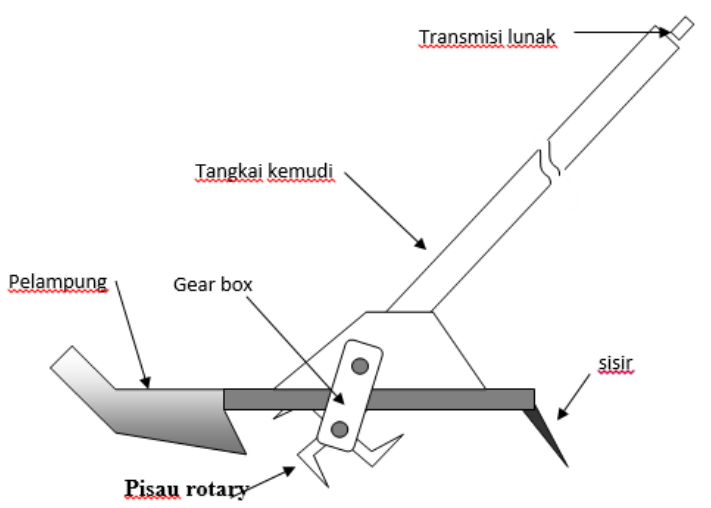

Gambar 2. Rancangan Mesin Penyiang Tampak Samping

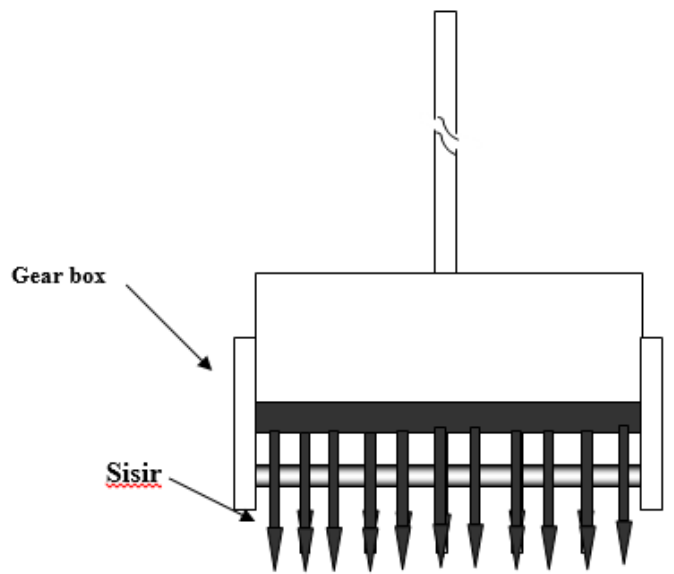

Gambar 3. Rancangan Mesin Penyiang Tampak Belakang

\section{HASIL DAN PEMBAHASAN}

Dalam kegiatan pengabdian ini ada beberapa tahapan pekerjaan yang harus dilakukan meliputi: koordinasi dengan mitra, perancangan dan pembuatan mesin yang akan 
diterapkan, uji coba mesin, penyerahan, dan evaluasi. Dari tahapan kegiatan tersebut yang telah dicapai meliputi:

1. Koordinasi dengan mitra

Dalam pelaksanaan kegiatan pengabdian ini kami tim selalu melakukan diskusi, meminta masukan dan juga saran. Hal ini dilakukan agar teknologi yang akan kita terapkan betulbetul digunakan oleh mitra dan mampu meningkatkan proses produksi baik dari segi kualitas maupun kuantitas. Dari hasil koordinasi ini mitra setuju dengan teknologi yang tim tawarkan.

\section{Perancangan dan pembuatan alat}

Dalam kegiatan pengabdian ini ada dua mesin penyiang yang akan diterapkan untuk dua mitra petani. Dalam proses pembuatan alat tersebut di atas ada beberapa tahapan yang akan dilakukan meliputi: perancangan, pemilihan bahan, pembelian bahan, pembuatan, perakitan dan uji coba.

\section{Uji Coba Alat}

Untuk mengetahui kemampuan dari alat yang telah dibuat maka dilakukan uji coba di lahan. Hasil dari uji coba ini sebagai bahan evaluasi untuk perbaikan alat. Berdasarkan hasil uji coba di lahan petani dengan umur tanaman 3 minggu setelah tanam, alat bisa digunakan dengan baik namun kecepatannya masih kurang yaitu dalam luasan $1 \mathrm{~m}^{2}$ bisa diselesaikan dalam waktu 25 menit. Selain itu, tanaman padi ikut terlilit pada putaran As roda. Kondisi ini memerlukan perbaikan di antaranya penambahan pipa pada As roda

\section{Penerapan Alat}

Setelah dilakukan perbaikan, alat penyiang gulma sistem landak bermotor bisa digunakan dengan baik. Dalam $1 \mathrm{~m}^{2}$ luasan lahan budidaya tanaman padi, bisa disiangi dalam waktu 10-15 menit. Hal ini sangat menguntungkan bagi petani sebab biaya yang harus dikeluarkan untuk tenaga kerja akan semakin berkurang dan waktu yang digunakan dalam kegiatan usaha tani akan semakin efisien.

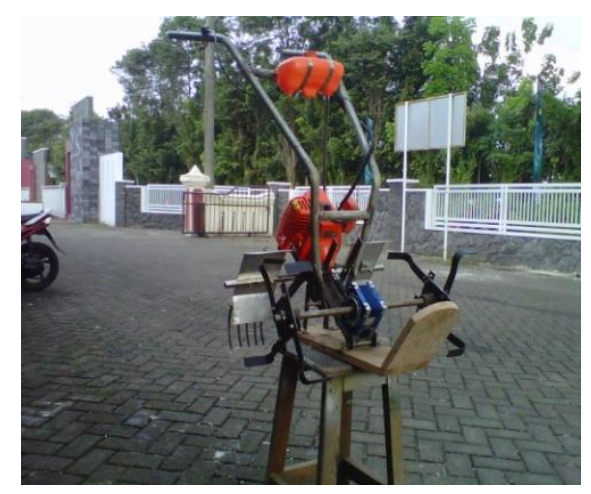

Gambar 4. Mesin Penyiang Hasil Rancangan

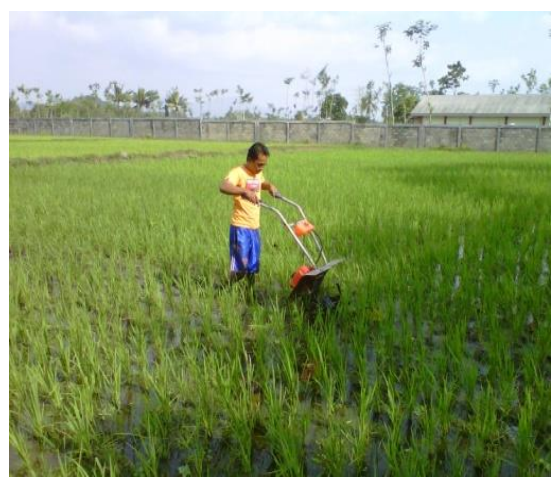

Gambar 5. Uji Coba di Lapang

\section{KESIMPULAN DAN SARAN}

Berdasarkan hasil kegiatan yang telah dilakukan dapat disimpulkan bahwa koordinasi selalu dilakukan dengan mitra sehingga terjalin hubungan yang lebih baik. Di samping itu, perancangan dan pembuatan mesin penyiang gulma tanaman padi telah diuji coba dengan hasil yang baik yaitu untuk luasan lahan $1 \mathrm{~m}^{2}$ mampu diselesaikan dalam waktu 10-15 menit dengan kondisi gulma yang tersiangi sempurna.

\section{DAFTAR PUSTAKA}

AAK. 1990. Budidaya Tanaman Padi. Yogjakarta: Kanisius. 
Henderson, 1986. Agriculturae Process Engineering. Westport Connecticut. AVI Publishing Company.

Kiyokatsu Suga dan Sularso. 1979. Dasar Perencanaan dan Pemilihan Elemen Mesin. Jakarta: PT Pradnya Paramita.

Singer, F.L dan A. Pytel. (Tanpa Tahun) Kekuatan Bahan (Teori Kokoh Strength Materials). Jakarta: Erlangga. 